\title{
Donations in kind: An investigation of the value for purposes of section 18A of the Income Tax Act
}

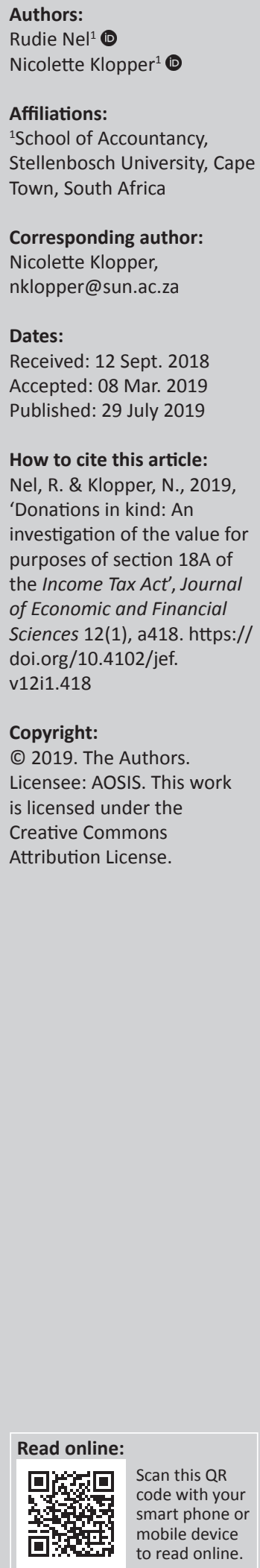

Orientation: The tax deductibility of donations in kind in terms of the Income Tax Act No. 58 of 1962 in South Africa.

Research purpose: The aim of this article is to critically analyse the provisions of section 18A(2) (a)(v) of the Income Tax Act No. 58 of 1962 to determine the value, if any, to be indicated on a section 18A receipt. It is also investigated whether the donee or donor is responsible for determining the fair market value, if such value should be included on a section 18A receipt.

Motivation for the study: Addressing uncertainty regarding which amount, if any, should be included on a section 18A receipt for tax purposes in respect of a donation in kind.

Research design, approach and method: This article involves a non-empirical interpretative analysis of tax legislation and other literature. The mode of inquiry for the article is qualitative in nature and follows a doctrinal method, which is closely associated with tax research.

Main findings: This article highlights the possible ambiguity in the interpretation of section 18A(2)(a)(v) of the Income Tax Act No. 58 of 1962 and that the term 'nature' could be construed as including a value.

Practical/managerial implications: The donor would have certain tax implications preceding a section 18A deduction which would require the donor to determine the fair market value and could enable the donor to also indicate such fair market value in respect of a donation in kind to the donee.

Contribution/value-add: This article contributes to literature by highlighting the uncertainty in respect of the interpretation of tax legislation relating to section 18A.

Keywords: donation in kind; property in kind; section 18A; section 18A receipt; fair market value.

\section{Introduction}

Section 55 of the Income Tax Act (the Act) defines a donation as meaning 'any gratuitous disposal of property including any gratuitous waiver or renunciation of a right'. Donations in kind have been argued as the low-hanging fruit of corporate philanthropy and an excellent way for business leaders to give back to society by leveraging their companies' strengths and assets (Scott 2014). In terms of the Tax exemption guide for public benefit organisations in South Africa, issued by the South African Revenue Service (SARS 2017), it is also widely accepted that the tax deductibility of donations, in cash or in kind, influences donor behaviour (Oberholzer 2004). The provisions in the Act affording a tax deduction should, however, also not result in uncertainty regarding the application thereof by a taxpayer.

The Organisation for Economic Co-operation and Development (OECD 2009) recognises that tax risk is generally attributable to the uncertainty of the interpretation of tax law in relation to particular transactions. Uncertainty and ambiguity regarding the interpretation and application of tax provisions could result in incorrect interpretation that results in incorrect application, whether deliberate or not. The uncertainty in this article is the practical application of the provisions of section 18A of the Act in respect of donations in kind relating to the value of such donations. Based on the literature surveyed, the responsibility of determining a value by the donee (issuing the required section 18A receipt) and the donor (completing a return to claim a deduction) is not evident. Any claim for a deduction by a taxpayer would only be allowed in terms of section $18 \mathrm{~A}(2)$ of the $A c t$, if supported by a receipt issued by a qualifying public benefit organisation (PBO) contemplated in section 30 of the Act and Part II of the Ninth Schedule to the Act. Should a cash donation be made by a company to an eligible PBO, the donee will be able to 
stipulate the actual cash value of the donation received on the section 18A receipt without any notion of ambiguity. The cash amount is given by the donor and subsequently documented on the section $18 \mathrm{~A}$ receipt received by the donor in return. However, should the donation be that of property made 'in kind', defined as 'payment in goods or services as opposed to money' (OxfordDictionaries.com 2018a), uncertainty arises as to the amount or nature of the donation to be included by the donee on the section $18 \mathrm{~A}$ receipt. Section $18 \mathrm{~A}(2)(\mathrm{a})(\mathrm{v})$ of the Act stipulates the following details to be provided on such a receipt: 'the amount of the donation or the nature of the donation (if not made in cash)' (emphasis added in italics).

Based on the interpretation of the wording, the use of 'or' could be interpreted as an alternative, namely that either the amount or the nature of a donation in kind should be indicated on a section 18A receipt. The uncertainty is whether for a donation in kind (if not made in cash) any amount should, in fact, be included on the receipt; and if held that the term 'nature' could be construed to include an amount to be included, the question remains whether the fair market value or cost price of the donation in kind should be indicated. The SARS does not provide a standard template or form to be used as a basis for the section 18A receipt, but notes that an organisation eligible to issue such a receipt may configure its own unique tax-deductible receipt to issue to the donor on condition that the requirements of the Act are met (SARS 2013a). The SARS has, however, issued two examples (SARS 2016a:22, 2017:81) to provide guidance. Both these examples appear the same on face value; however, the details illustrated in terms of a donation not in cash differ, as is evident from Figures 1 and 2.

The more recent example in Figure 1 provides no further guidance on the details of a donation in kind, whereas the older example in Figure 2 stipulates a description, the value and details of how the value was determined. The recent example in Figure 1 lacks guidance on what is meant by nature by the inclusion of the blank space, as opposed to the preceding example in Figure 2. The lack of guidance on the details that should be included on a section $18 \mathrm{~A}$ receipt could

NATURE OF DONATION (IF NOT IN CASH)

Source: South African Revenue Service (SARS), 2017, Tax exemption guide for public benefit organisations in South Africa (issue 5), p.81, SARS, Pretoria

FIGURE 1: Extract from example provided by South African Revenue Service.

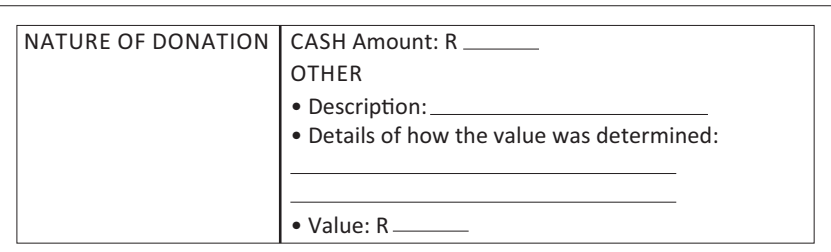

Source: South African Revenue Service (SARS), 2016a, Basic guide to tax-deductible donations (issue 2), p. 22, SARS, Pretoria

FIGURE 2: Extract from example provided by South African Revenue Service. result in different interpretation and application by taxpayers, resulting in possible errors, inadvertent or intentional, in completing tax returns.

\section{Research objective, research method and value of the research}

The objective of this article is to critically analyse the application of the provisions of section 18A of the Act in respect of donations of property in kind relating to the value of such donations. The article involves an interpretative analysis of the tax legislation and incorporates other literature. The mode of inquiry for the article is qualitative in nature and follows a doctrinal method, as described by McKerchar (2008). In terms of this method, the specific requirements of the Act were firstly identified and the issues regarding interpretation from a legislative perspective were analysed. This was followed by the identification of sources, of which the primary sources were accepted as case law, interpretations by and guides from SARS. Secondary sources were accepted as articles, dissertations and academic books. The sources were consulted to obtain an understanding of the interpretation of the current provisions of the Act in the absence of guidance specifically pertaining to the details required on a section $18 \mathrm{~A}$ receipt in respect of the value of donations of property in kind. The investigation of the provisions of section 18A of the Act is made from the perspective of the donee and thereafter the donor. The donee would, firstly, have to issue the required section $18 \mathrm{~A}$ receipt, which would enable the donor to claim a deduction on completion of a return.

The value of this article lies in highlighting the uncertainty regarding the details required on a section 18A receipt. Guidance is then formulated based on any uncertainty highlighted regarding the application of section 18A of the Act in respect of the value of a donation of property in kind. As a point of departure, the term 'nature' was analysed to determine whether 'nature' requires an amount to be included. Thereafter the meaning of 'value' was analysed to determine whether the cost price or fair market value should be indicated on a section 18A receipt, as influencing the subsequent value indicated by the donor in completion of the return. The investigation would consequently be performed by addressing the following three questions:

- Would the term 'nature' include an amount to be provided on the section 18A receipt?

- Which value should be indicated by the donee on the section 18A receipt?

- Which value should be indicated by the donor on completion of the tax return?

\section{Would the term 'nature' include an amount to be provided on the section $18 \mathrm{~A}$ receipt?}

The modern approach to interpretation of legislation from the outset considers the context and the language together, with neither predominating over the other (Jaga $v$ Dönges 
NO E another, Bhana v Dönges NO \& another 1950 (4) SA 653 (A) at 662G-663A; Natal Municipal Joint Pension Fund v Endumeni [2012] (4) SA 593 (SCA) 16). This approach to interpretation insists that context be considered in the first instance, especially in the case of general words, and not merely at some later stage when ambiguity might be thought to arise. In the case of ambiguity arising during the interpretation, the contra fiscum rule will be applicable (Estate Reynolds and Others $v$ CIR [1937] AD 57). The contra fiscum rule is a common law principle, stipulating that should a taxing statutory provision reveal an ambiguity, the ambiguous provision must be interpreted in a manner that favours the taxpayer (Badenhorst v CIR 1955 (2) SA 207 (N) 215; Legwaila \& Ngwenya 2013). In Shell's Annandale Farm (Pty) Ltd v CSARS [2000] 62 SATC 97, the Cape High Court judged that the contra fiscum rule can be invoked where a statutory provision is ambiguous as to the intention of the legislature, and if such ambiguity is reasonably 'implied from the wording of the legislation and such legislation implies a burden upon the subject then that interpretation must be adopted which is in favour of the taxpayer' (Cliffe Dekker Hofmeyr 2016).

The British and World English translations of the English Oxford Living Dictionaries define 'nature' as 'the basic or inherent features, character or qualities of something' (OxfordDictionaries.com 2018b). The US English translation of the Oxford English Dictionary defines 'nature' as 'existing in something as a permanent, essential, or characteristic attribute' (OxfordDictionaries.com 2018b). Given the wide meaning of 'nature', it is submitted that one of the qualities of a donation could be the value of the donation. The phrase 'the nature of' is, however, applied in various provisions of tax Acts administered by the SARS besides section 18A of the Act. The meaning intended in the other provisions of tax Acts was also analysed for guidance on the context within the Act that could differ from the broad ordinary meaning according to dictionaries.

South African courts have had regard to 'the nature of' expenditure incurred in deciding whether a company has traded (SARS 2005:4). In considering the nature of expenditure, the focus is on the classification of the expenditure without any consideration of the amount or value of the expenditure, therefore indicative of 'nature' of the expenditure not being dependent on the amount or value of such expenditure (based on interpretation of SARS [2005:4]). The SARS has also issued guidance on 'the nature of' allowances, advances and reimbursements, focusing on the classification of such receipt by the employee and not the amount or value of the receipt (SARS 2013b:3). South African courts have also considered 'the nature of' rights under transactions referring to the classification as capital or revenue in nature as a separate issue to the timing and valuation of the amounts involved (SARS 2012). The interpretation of a concept that is not defined in the Tax Court Rules, the Income Tax Act or any other tax Act, could eventually appear before the Courts (Areias \& Kotze 2013).
To investigate different possible interpretations, the meaning of terms in the different tax Acts has also been considered previously (Haupt \& Nel 2017:16). Inference could therefore be made on the definition or meaning ascribed in other tax Acts apart from the Income Tax Act if not defined in the Act itself, unless the context of such interpretation clearly differs. A more pertinent use of wording can also be found in section 18(8) and section 21 of the Value-Added Tax Act No. 89 of 1991 (VAT Act), where 'the nature of' a supply is separately listed from the consideration (amount) relating to the supply (Republic of South Africa 1991).

Despite the ordinary broad meaning of 'nature', which could be interpreted as including an amount, the context within the tax Acts suggests a narrower meaning. Based on the guidance considered in respect of the wording 'the nature of' applied in other provisions of tax Acts, the focus is on the classification of the underlying object and would not necessarily include the amount in respect of the underlying object. The wording in section $18 \mathrm{~A}(2)(\mathrm{a})(\mathrm{v})$ of 'nature of' would therefore not necessarily require an amount to be included in the description of a section 18A receipt, but rather the 'nature of' a donation would then require a description of the type of property in kind donated. This submission would comply with the more recent example issued by the SARS (Figure 1), in which no value is included in the detailed example compared to the older example in Figure 2. If the older example (Figure 2) is applied, the uncertainty that arises is whether the fair market value or the cost price should be included on the section 18A receipt. The position of the donee and the donor is subsequently analysed to explore the possible value that would be relevant to each of the parties' tax position as a result of a section $18 \mathrm{~A}$ donation.

\section{Which value should be indicated by the donee on a section $18 \mathrm{~A}$ receipt?}

An organisation exempt from income tax must provide the total amount received from foreign and local sources as part of the organisation's general financial information upon completion of their required tax returns (SARS 2014). The total value of donations for which section 18A-deductible receipts were issued must also be submitted by the exempt organisation (SARS 2014). No guidance is, however, given regarding which value should be included in instances where donations of property in kind are received. Section 18A(3) and subsections (3A) to (3B) of the Act provide guidance for determining the deduction of the donor in respect of a donation of property in kind, but does, however, not pertinently refer to the position of the donee receiving the donation. As the donor and the donee are separate persons as defined in section 1 of the Act, the normal tax consequences would be determined separate from each other in terms of section 5 of the Act. The position of the donee is therefore submitted as being separate from the position of the donor in respect of the deduction, and therefore requires separate investigation. 
If the donee interprets the requirements of section 18A(2)(a) (v) of the Act as including a value as part of the 'nature' on a receipt, either the cost price or the fair market value could possibly be indicated on a section $18 \mathrm{~A}$ receipt. As a donation of property in kind would constitute a receipt other than in cash by a $\mathrm{PBO}$, the landmark principle established in the case of W H Lategan v CIR, 1926 CPD 203, 2 SATC 16, is applied, which would result in the value of the property being considered. The receipt would therefore be valued at the fair market value of the property received. Determining the fair market value of property received in kind would differ based on the property in question and could also have varying cost implications. Determining the fair market value of listed shares would not entail any cost implications as the listed price of the particular share would be readily available (JSE n.d.). The fair market value of fixed property donated could also be determined by valuation, but would entail varying valuation costs to be incurred as determined, inter alia, on the value of the property and the experiences of the property valuer (South African Council for the Property Valuers Profession 2010). Similarly, the fair market value of intangible assets donated could also entail valuation costs to be incurred. The delicate and complex issue of valuing intangible assets, which can be valued by different techniques, has been recognised (Van der Walt 2010:100). Expenditure would therefore be incurred in maintaining the value of the intangible assets, which could also not be differentiated from investments in enhancing value (Van Der Walt 2010:61). The valuation of intangible assets is therefore submitted as more complex than valuing shares and fixed property because of the complicated nature of intangible assets.

A disadvantage of indicating the fair market value as the value of the donation on a section 18A receipt is therefore the possible resulting costs to perform the valuation, as enunciated in the preceding paragraph, which would have to be incurred. Having regard for the intention of donations to enable the donee to generate funds to pursue activities in the interest of the common good, the resulting valuation costs a donee would be required to incur would reduce the available funds of the donee. Furthermore, the existing increased compliance burden of PBOs has also been highlighted based on other tax amendments introduced (Warneke 2015). Considering the possible costs involved as well as the existing compliance burden of PBOs, two alternatives to the donee indicating the fair market value on a section 18A receipt could be (1) for the donor to indicate the cost price to the donee, or (2) for the donor to provide the fair market value to the donee.

As first alternative, the cost price to the donor could be indicated and would not entail valuation costs to be incurred. The inclusion of the cost price to the donor on the section 18A receipt would, however, require the donee to be privileged to the information of the donor or require that the information be explicitly provided by the donor. Furthermore, as the donee would be required to include the value of donations received in their own tax return, the cost price to the donor would not be considered suitable as the value of the donation received by the donee. Based on the preceding, the first alternative is not submitted as the preferred alternative. As second alternative, the requirement could be for the donor to provide the fair market value of the property donated to the donee, which is analysed in the section that follows by considering the tax position of the donor as a result of a section $18 \mathrm{~A}$ donation.

\section{Which value should be indicated by the donor in completion of a tax return?}

The value of the amount donated to the relevant organisation during the year of assessment should be submitted by a donor in his or her income tax return (SARS $2016 \mathrm{~b})$. The value of a donation of property in kind is stipulated in section $18 \mathrm{~A}(3)$ and section $18 \mathrm{~A}(3 \mathrm{~A})$ of the $A c t$ in respect of a deduction claimed by a taxpayer. The value of property donated, other than limited interests, is the price that a willing buyer and a willing seller in an open market would agree upon in an arm's length transaction, known as the fair market value (Oosthuizen \& Stiglingh 2018:913). In assessing taxable income, the section 18A deduction is the last deduction when calculating taxable income of a natural person in terms of section 18A(1)(B) of the Act (Van Heerden 2018:161). The provisions of section 18A are, however, not only limited to natural persons, but also applied to persons other than natural persons, such as companies (Wilcocks 2019:330). As the last deduction it would entail that the section 18A deduction is preceded by other tax consequences in respect of the underlying property donated in the current or preceding years of assessment. For the donation of property in kind consisting of an asset, the donor could have qualified for deductions and allowances until such time the property is donated. On donation of the property the donor could then have a recoupment as a result of previous deductions or allowances claimed in terms of section 8(4) of the Act. If the fair market value on the date of the donation exceeds the base cost of the property, the donor could also have possible capital gains tax consequences in terms of the Eighth Schedule to the Act. The eventual donation of the property is therefore preceded by certain other tax consequences, which is illustrated in Figure 3.

Based on the preceding tax consequences in terms of the Act, it is submitted that the donor as taxpayer would have to determine the fair market value of the property donated in kind for purposes of normal tax treatment preceding a section 18A deduction. Section 102 of the Tax Administration Act No. 28 of 2011 (RSA 2011) determines that the taxpayer also bears the burden of proof that a valuation is correct. As the donor would have burden of proof for a deduction and tax consequences preceding the eventual deduction, it would also require the donor to determine the fair market value. If 


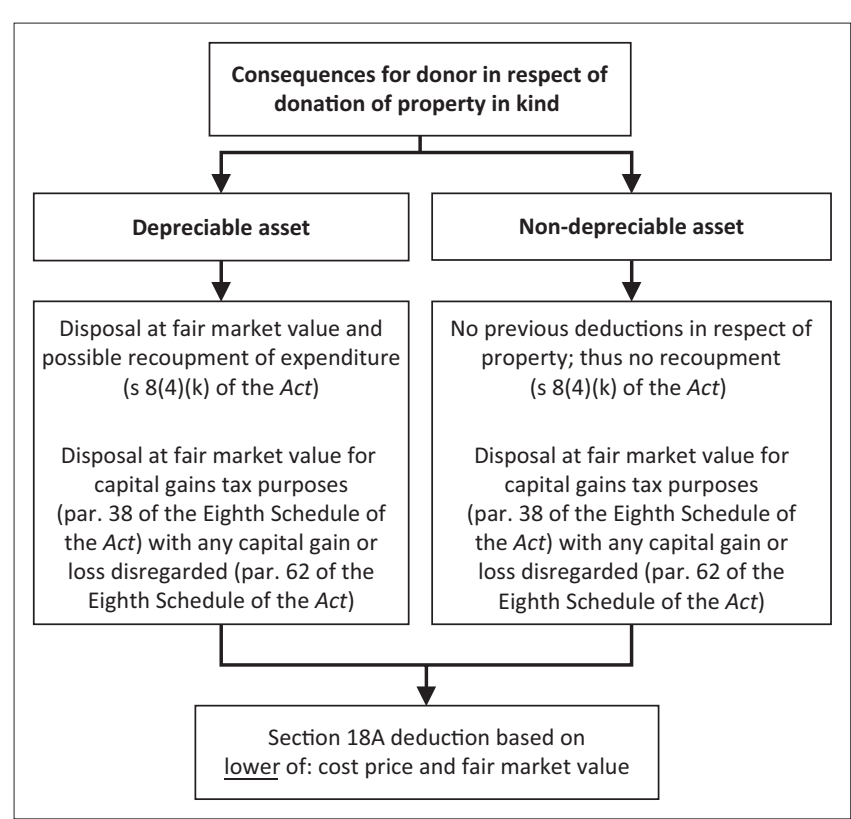

FIGURE 3: Consequences for donor in respect of donation of property in kind.

the donor values the property donated, the donee would not also have to value the property, which could further reduce the compliance burden of the donee. It is, however, recognised that a difference in timing exists between the date of a donation, when the section $18 \mathrm{~A}$ receipt is issued, and the date the donee submits a tax return. The date of the donation and the date of issue of the section 18A receipt would occur during the year of assessment in which the donation is made (Wilcocks 2019:330). In terms of section 66(13) of the Act, a return is required for a year of assessment, once the Commissioner has given notice, therefore implying at the end of the year of assessment. The date of donation therefore precedes the date on which the donor submits a tax return. A donor would make a donation during a year of assessment; however, the submission of a tax return would only be after the year of assessment during which the donation occurred. At the time of the donation, the donor would therefore not have the immediate obligation to determine the fair market value as this requirement would only have to be met upon the subsequent completion of a tax return. The donor would, however, still bear the burden of proof of a valuation in terms of section 102 of the Tax Administration Act and such a determination could still be performed on the date of a donation.

\section{Conclusion}

In investigating the value contemplated in section 18A of the Act, either the fair market value or the cost price of donations in kind could be indicated on a section 18A receipt. Based on an analysis of the meaning of 'nature of' contemplated in other provisions of tax Acts, a narrower meaning was found that possibly would not require an amount to be included. On the contrary, the ordinary meaning of 'nature' could, however, still afford interpretation of 'nature' to include an amount or value. This submission is supported by the example provided in SARS (2016a:22) (see Figure 2), which indicates a value in an example of a section 18A receipt. If the interpretation is that a value should be indicated, the question arises as to which value (cost or fair market value) should be indicated and whether the donee or the donor is responsible to determine such a value.

Based on the consideration of the position of the donee and the donor as result of a section 18A donation, it was found that the donee would have to include the fair market value of donations received in the completion of their tax returns. The donor would also have the obligation to determine the fair market value upon completion of their tax return in claiming a deduction. As the donee is not privy to the cost price to the donor, without specific disclosure by the donor, the donee could include the fair market value of such a donation on a section 18A receipt as well as in completion of their own tax return. The determination of the fair market value could entail certain expenditure for the donee, which is argued as not being in the spirit of encouraging the donee to pursue activities in the interest of the common good. The position of the donor would necessitate the determination of the fair market value of the property donated in kind to establish the possible recoupments and capital gains tax in respect of the property (see Figure 3). The determination of the fair market value is therefore submitted as the responsibility of the donor based on the preceding tax events leading up to a section $18 \mathrm{~A}$ deduction by the donor.

However, the alternative that the donee should determine the market value could also be argued. The fact that the donee receives the benefit in respect of the donation in kind could warrant the donee to incur the applicable valuation cost. If the donee determines the market value and indicates such value on the section $18 \mathrm{~A}$ receipt, the donor would have the market value required in the preceding tax events of the donor. The fact that the donor will then not have to determine market value could serve as an incentive to encourage donations in kind as it would not place additional obligations on the donor in respect of such donation.

In conclusion, the wording of section $18 \mathrm{~A}(2)(\mathrm{a})(\mathrm{v})$ of the Act affords interpretation for the donee to include an amount or value on a section $18 \mathrm{~A}$ receipt. The ambiguity highlighted by this article is in the current guidance in examples provided by the SARS of section $18 \mathrm{~A}$ receipts of which the most recent does not explicitly stipulate a value to be included; however, the preceding example did stipulate a value. Any ambiguous provisions should, based on the contra fiscum rule, be interpreted in favour of the taxpayer. In the context of the donee issuing a receipt, it is submitted that the fair market value required to be determined by the donor should be provided to the donee to prevent additional expenditure being incurred by the donee in determining the fair market value of the donation of property in kind. This recommendation would result in the donor having to determine the value on the date of the donation and not on completion of a tax return, which is usually the case. The resulting difference in timing of the obligations of the 
donor is as a result recognised and should also be considered in formulating future official guidance. The practical implications and policy implication of the findings of the article could also inform future discussion on the topic and possibly also be considered in the formulation of future guidance in respect of the normal tax treatment of donations of property in kind in terms of section 18A of the Act.

A well-designed tax system that incentivises charitable donations is a way in which government can provide much needed support to welfare organisations (Steenkamp 2014). If the uncertainty highlighted in this article is resolved by further guidance based on consultation, the design of the current provisions of the Act could be improved and possibly encourage further support of welfare organisations.

\section{Acknowledgements Competing interests}

The authors declare that they have no financial or personal relationships that may have inappropriately influenced them in writing this article.

\section{Authors' contributions}

The article was written in equal parts by both authors.

\section{Ethical considerations}

The article was submitted for ethical clearance at Stellenbosch University Research Ethics Committee: Human Research (Humanities) and received approval with review reference number: ACC-2018-6334.

\section{Funding}

This research received no specific grant from any funding agency in the public, commercial or not-for-profit sectors.

\section{Data availability statement}

Data sharing is not applicable to this article as no new data were created or analysed in this study.

\section{Disclaimer}

The views expressed in this article are those of the authors and do not necessarily reflect the official policy or position of any affiliated agency of the authors.

\section{References}

Areias, D. \& Kotze, J., 2013, 'A departure from "adequate reasons" and common sense: Focus', TAXtalk 2013(41), 54-57.

Badenhorst v CIR 1955 (2) SA 207 (N) 215.

Cliffe Dekker Hofmeyr, 2016, 'Contra fiscum rule applied', Integritax 2550(204), viewed 31 May 2018, from https://www.saica.co.za/integritax/2016/2550. Contra_fiscum_rule_applied.htm.

Estate Reynolds and Others v CIR 1937 AD 57
Haupt, E. \& Nel, R., 2017, 'Dividend cession and dividend distribution: The South African VAT implications', Journal of Economic and Financial Sciences 10(1), 13-25. https://doi.org/10.4102/jef.v10i1.2

Jaga v Dönges NO \& another, Bhana v Dönges NO \& another 1950 (4) SA 653 (A) at 662G663A.

JSE, n.d., Share Watchlist, viewed 07 March 2019, from https://www.jse.co.za/growmywealth/share-watchlist.

Legwaila, T. \& Ngwenya, L., 2013, 'A (Pty) Ltd v The Commissioner for the South African Revenue Service ITC 12644 (2012)', De Jure 46(4), 1066-1077.

McKerchar, M.A., 2008, Philosophical paradigms, inquiry strategies and knowledge claims: Applying the principles of research design and conduct to taxation, viewed 31 May 2018, from https://papers.ssrn.com/sol3/papers.cfm?abstract_ $i d=1464141$.

Natal Municipal Joint Pension Fund v Endumeni [2012] (4) SA 593 (SCA) 16.

Oberholzer, R., 2004, 'The tax deductibility of donations, with specific reference to donations of property made in kind to public benefit organisations', Southern African Business Review 8(3), 68-75.

Oosthuizen, R. \& Stiglingh, M., 2018, 'Donations tax', in M. Stiglingh, A. Koekemoer, L. Van Heerden, J.S. Wilcocks, R. De Swardt \& K. Jordaan (eds.), SILKE: South African income tax, pp. 906-919, LexisNexis, Durban.

Organisation for Economic Co-operation and Development (OECD), 2009, Forum on tax administration. Information note general administrative principles: Corporate governance and tax risk management, viewed 31 May 2018, from http://www. oecd.org/dataoecd/37/19/43239887.pdf.

OxfordDictionaries.com, 2018a, In kind, viewed 31 May 2018, from https:// en.oxforddictionaries.com/definition/in_kind.

OxfordDictionaries.com, 2018b, Nature, viewed 31 May 2018, from https:// en.oxforddictionaries.com/definition/us/nature.

Republic of South Africa (RSA), 1962, Income Tax Act, No. 58 of 1962 (as amended), Government Printer, Pretoria.

Republic of South Africa (RSA), 1991, VAT Act No. 89 of 1991 (as amended), Government Printer, Pretoria.

Republic of South Africa (RSA), 2011, Tax Administration Act, No. 28 of 2011 (as amended), Government Printer, Pretoria.

Scott, R., 2014, Breaking down the benefits of in-kind giving - And the regulations around it, viewed 31 May 2018, from https://www.forbes.com/sites/ causeintegration/2014/03/30/kinds-of-givinginkind/\#470636b46d75.

Shell's Annandale Farm (Pty) Ltd v CSARS [2000] 62 SATC 97.

South African Council for the Property Valuers Profession, 2010, Guideline professiona Fees, viewed 07 March 2019, from https://www.sacpvp.co.za/page/fees.

South African Revenue Service (SARS), 2005, Interpretation note no. 33, viewed 16 November 2018, from http://www.sars.gov.za.

South African Revenue Service (SARS), 2012, Interpretation note no. 58 (issue 2), viewed 16 November 2018, from http://www.sars.gov.za.

South African Revenue Service (SARS), 2013a, FAQ: Does SARS have a template/ form it makes available for tax deductible receipts to PBOs approved for section 18A purposes?, viewed 18 March 2016, from http://www.sars.gov.za/FAQs/ Pages/253.aspx.

South African Revenue Service (SARS), 2013b, Interpretation note no. 14 (issue 3), viewed 16 November 2018, from http://www.sars.gov.za.

South African Revenue Service (SARS), 2014, How to complete the return of income: Exempt organisations (IT12EI return), viewed 03 April 2018, from https://www. scribd.com/document/299516611/IT-AE-36-G01-Quick-Guide-on-HowtoComplete-the-IT12EI-Return-forExempt-Organisations-External-Guide.

South African Revenue Service (SARS), 2016a, Basic guide to tax-deductible donations (issue 2), SARS, Pretoria.

South African Revenue Service (SARS), 2016b, Comprehensive guide to the ITR14 return for companies - External guide (revision 6), SARS, Pretoria.

South African Revenue Service (SARS), 2017, Tax exemption quide for public benefit organisations in South Africa (issue 5), SARS, Pretoria.

Steenkamp, L.A., 2014, 'Public benefit organisations and tax: Where is the charity and justice?: Features', TAXtalk 2014(45), 27-31.

Van der Walt, D., 2010, 'Valuation of intellectual property and intangible assets', Unpublished Master's thesis, University of Johannesburg, South Africa.

Van Heerden, L., 2018, 'Natural persons', in M. Stiglingh, A. Koekemoer, L. Van Heerden, J.S. Wilcocks, R. De Swardt \& K. Jordaan (eds.), SILKE: South African income tax, pp. 137-174, LexisNexis, Durban.

Warneke, D., 2015, 'Increased compliance burden on the cards for PBOs: Technical', TAXtalk 2015(50), 62-63.

W H Lategan v CIR, 1926 CPD 203, 2 SATC 16.

Wilcocks, J., 2019, "'Special deductions and assessed losses" and "Capital allowances and recoupments"', in M. Stiglingh, A. Koekemoer, L. Van Heerden, J.S. Wilcocks \& P. Van der Zwan (eds.), SILKE: South African income tax, pp. 299-343, LexisNexis, Durban. 